\title{
Measurements of size-resolved hygroscopicity in the California coastal zone
}

\author{
D. A. Hegg ${ }^{1}$, D. S. Covert ${ }^{1}$, and H. H. Jonsson ${ }^{2}$ \\ ${ }^{1}$ Department of Atmospheric Sciences, University of Washington, Seattle, WA, USA \\ ${ }^{2}$ Meteorology Department, Naval Post Graduate School, Monterey, CA, USA \\ Received: 26 February 2008 - Published in Atmos. Chem. Phys. Discuss.: 3 June 2008 \\ Revised: 20 October 2008 - Accepted: 20 October 2008 - Published: 9 December 2008
}

\begin{abstract}
Aircraft-based measurements of aerosol hygroscopicity, both in the form of size-resolved, diameter growth factors and in the dependence of particle light scattering on relative humidity, are presented for the marine boundary layer of the southern California coastal zone. The chemical composition of the aerosol is collated with the hygroscopicity data, both to examine the mechanism for the increase in aerosol hygroscopicity with altitude and as input for receptor type modeling. The data suggest an increase in aerosol hygroscopicity with altitude, possibly associated with oxidation of organic films. The receptor modeling suggests three distinct aerosol types/sources for this venue: marine, biomass burning and pollution. Model output is used in regression analyses to derive a prognostic mixing rule for the hygroscopicity of aerosol with these three sources. The mixing rule demonstrated substantial prognostic power for submicron hygroscopicity but essentially none for supermicron.
\end{abstract}

\section{Introduction}

The facility with which atmospheric aerosols absorb water as a function of ambient relative humidity (RH), called the aerosol hygroscopicity, is a very important aerosol characteristic, impacting the chemical reactivity of the aerosol, its ability to act as cloud condensation nuclei (CCN) and direct aerosol radiative forcing in the atmosphere (Rossi, 2003; Rudich, 2003; Poschl et al., 2007; Gasparini et al., 2006; Charlson et al., 1992; Hegg et al., 1997). The well-known

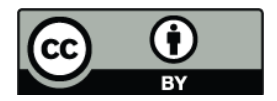

Correspondence to: D. A. Hegg (deanhegg@atmos.washington.edu) size dependence of aerosol composition, coupled with the dependence of hygroscopicity on composition, leads to a clear hygroscopicity size dependence in atmospheric aerosols, a dependence well documented at sub-micron sizes (cf. Swietlicki et al., 2000; Santarpia et al., 2004) but significantly less so at larger sizes (e.g. Hitzenberger et al., 1997; Kreisberg et al., 2001; Hegg et al., 2006).

Given this importance, it is scarcely surprising that a substantial research effort has been devoted to measuring and understanding the hygroscopicity of atmospheric aerosols. Despite this, many important issues remain unresolved. As alluded to above, the hygroscopicity of ambient aerosols larger than $1 \mu \mathrm{m}$ is poorly documented. Changes in aerosol hygroscopicity with aging, due primarily to chemical reaction, are far from well understood. More inclusively, understanding (in a prognostic sense) the manner in which different aerosol types, from different sources, combine to produce the overall hygroscopicity of the typically internally-mixed atmospheric aerosol is poorly understood (i.e. a source budget for aerosol hygroscopicity is not yet in hand).

To address parts of this issue we have performed an aircraft-based experiment with the goals of better documenting the aerosol hygroscopicity, both in the form of diameter growth factors and the dependence of particle light scattering on $\mathrm{RH}$, and of relating these properties to aerosol chemical composition. We present new data on aerosol hygroscopicity, including size-resolved hygroscopicity up to a particle diameter of $3 \mu \mathrm{m}$, in an important aerosol venue. We also analyze the sources of aerosol hygroscopicity using receptor modeling, and evaluate a particular methodology for combining the hygroscopicity of different aerosol types/sources to produce the overall aerosol hygroscopicity. 


\section{Methodology}

The central measurement in the analysis presented here is that of aerosol hygroscopicity. This aerosol characteristic is measured via two techniques, utilizing two different instruments. The first such technique measures the sizeresolved change in aerosol diameter with relative humidity using the Aerosol Hydration Spectrometer (AHS) described in Hegg et al. (2007). This instrument is essentially two optical particle counters maintained at two distinct relative humidities (a nominal 45 and 85\% RH for ambient measurements). The measurements are converted to hygroscopic growth factors using the Descriptive Hygroscopic Growth Factor (DHGF) methodology of Nowak (2005) as described in Hegg et al. (2006, 2007). Since the AHS has a lower size limit of about $0.3 \mu$ m diameter, it does not sense a substantial portion of typical aerosol size distributions, either with respect to mass or light-scattering. Because of the intrinsic importance of the effect of hygroscopicity on aerosol light scattering, we have therefore utilized a second technique and associated instrument to measure the $\mathrm{RH}$ dependent light scattering of the ambient aerosol. This instrument, a lightscattering humidigraph, uses three nephelometers to measure the light-scattering coefficient at three humidities, nominally 30, 60 and 85\% RH (cf. Gasso et al., 2000; Hegg et al., 2002). It should be noted that, while most of the issues associated with the change in the optical response of the particles upon hydration are dealt with in the above citations, one that is not is the possibility of, for significantly absorbing aerosols, enhanced absorption due to lensing effects in the larger drops. Since such effects have been shown to be negligible for even cloud drops (Liu et al., 2002), we assume there is no effect for our cases.

To characterize the chemical composition of the aerosol, filter sampling was employed. By far the most prevalent technique was with $47 \mathrm{~mm}$ Teflo membrane filters with a $2 \mu \mathrm{m}$ pore size. On a few occasions, sufficient sampling time was available to collect size-resolved filter samples via 5 stage Micro Orifice Impactors (MOI) followed by a filter backup. The substrates for this type of sampling were $\mathrm{Ze}$ fluor Teflon filters $(1 \mu \mathrm{m}$ pore size). Both substrates have collection efficiencies in excess of $99.99 \%$ for $0.2 \mu \mathrm{m}$ particles and larger. After collection, samples were stored at a nominal $4{ }^{\circ} \mathrm{C}$ prior to analysis. The samples were analyzed over a week's time. All substrates were analyzed gravimetrically and then extracted in $10 \mathrm{ml}$ of HPLC water. The extracts were then analyzed by standard Ion Chromatography (IC) for anions (both organic and inorganic), Liquid Chromatography - Mass Spectroscopy (LC-MS) for carbohydrates, and Inductively Coupled Plasma - Optical Emission Spectroscopy (ICP-OES) for a suite of trace elements (cf. Gao et al., 2003a). Additionally, in order to quantify the concentration of black carbon present (important both optically and as an aerosol source tracer), we used a three wavelength Particle Soot Absorption Photometer (PSAP) to measure the aerosol absorption coefficient (Virkula et al., 2005). We then employed a specific black carbon absorption coefficient of $7 \mathrm{~m}^{2} \mathrm{~g}^{-1}$ to convert the absorption to black carbon mass concentration (cf. Bond and Bergstrom, 2006).

The instruments described above were deployed from an airborne platform, the Center for Interdisciplinary Remotely Piloted Aircraft Studies (CIRPAS) Twin Otter research aircraft. This platform, and its associated facility instruments, has been described in a number of publications (e.g. Wang et al., 2002; Schmid et al., 2003; Hegg et al., 2005). More specific information will be related, as necessary, in the discussion.

The aerosol chemical composition can, of course, be used to evaluate possible aerosol sources. However, unless the source compositions are well characterized, and differ significantly from one another, fully deterministic assessment, using tools such as a chemical mass balance model, is not really feasible. Such is the case here and to address the issue of sources of aerosol hygroscopicity, we have employed alternative ANOVA techniques, namely, various forms of factor analysis. Specifically, we have used, in addition to the standard factor analysis with principal component extraction (cf. Gao et al., 2003b), the EPA PMF 1.1 and UNMIX 2.3 models. These are operational, regulatory, receptor models used precisely to deconvolute aerosol sources when good source profiles are not available. Numerous examples of their application to such issues are in the literature (e.g. Kim et al., 2004; Willis et al., 2001).

\section{Venue}

The measurements reported here were acquired during the CARMA-IV field campaign. The CARMA (Cloud-Aerosol Research in the Marine Atmosphere) Project has been an ongoing effort to elucidate both the direct and indirect effects of aerosols on marine boundary layer structure and the radiative balance of the marine atmosphere. Our current specific goals (as per the above discussion) thus fit comfortably into the CARMA framework.

The venue for the CARMA measurements is the California coastal zone, extending from $37.2 \mathrm{~N}$ Latitude to $34 \mathrm{~N}$ latitude and from the coastline to $\sim 300 \mathrm{~km}$ offshore. This location is well suited to the study goals for a number of reasons. It is one of the three most intensive stratocumulus areas in the world (Warren et al., 1988) and the clouds have been shown susceptible to both microphysical and radiative perturbation by aerosols (cf. Platnick and Twomey, 1994; Durkee et al., 2000 and references therein). Most relevant to the present study, it is also an area in which the aerosol is impacted by a number of different sources, including biomass burning, pollution and the ocean surface. This leads to a wide range in both aerosol composition and other derivative properties, most relevantly for this study, the aerosol hygroscopicity. Airborne sampling was done throughout this region in the 


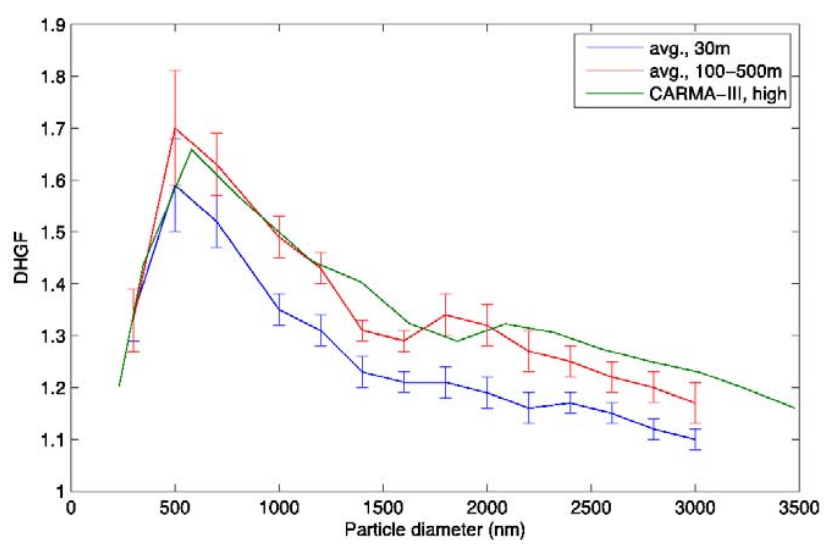

Fig. 1. The change in the mean DHGF spectrum with altitude during the study period.

course of 15 flights conducted during August 2007. Horizontal traverses of the marine boundary layer (MBL), normally at least three per flight and typically at $30 \mathrm{~m} \mathrm{MSL}$ and also $100-500 \mathrm{~m}$ but below cloud base (when present) were made. From this set, 24 traverse were applicable to this study and are analyzed here.

\section{Results and discussion}

\subsection{Observed marine DHGF spectra}

The DHGF spectra observed in the course of this study were, in general, quite similar to those we observed in this same venue during the CARMA-III measurement campaign in August of 2005 (Hegg et al., 2007). The average of marine spectra sampled at $30 \mathrm{~m} \mathrm{MSL}$ and in the range $100-500 \mathrm{~m} \mathrm{MSL}$ from CARMA-IV are shown in Fig. 1. The higher-level average spectrum from CARMA-III ( $\sim 250 \mathrm{~m} \mathrm{MSL})$ is also shown for comparison. A striking feature of all the spectra is the fall off in hygroscopicity with size above $\sim 700 \mathrm{~nm}$. This is at first glance surprising since one would expect the larger particles to have a strong sea salt component. However, chemical composition data presented below, together with previous compositional measurements in this venue (Hegg et al., 2006), show that the supermicron aerosol have major sulfate and soil dust components and should not be considered sea salt. This is in fact consistent with our current understanding of the Northern Hemispheric background aerosol (Andreae, 2007).

The magnitudes of the DHGF values are very similar for the two campaigns and, in both campaigns, the higher altitude spectra show more hygroscopicity, though the difference is significant over a broader range in the current data set. In particular, the super-micron hygroscopicity changes much more substantially with altitude in the CARMA-IV campaign. In assessing the CARMA-III data, we suggested

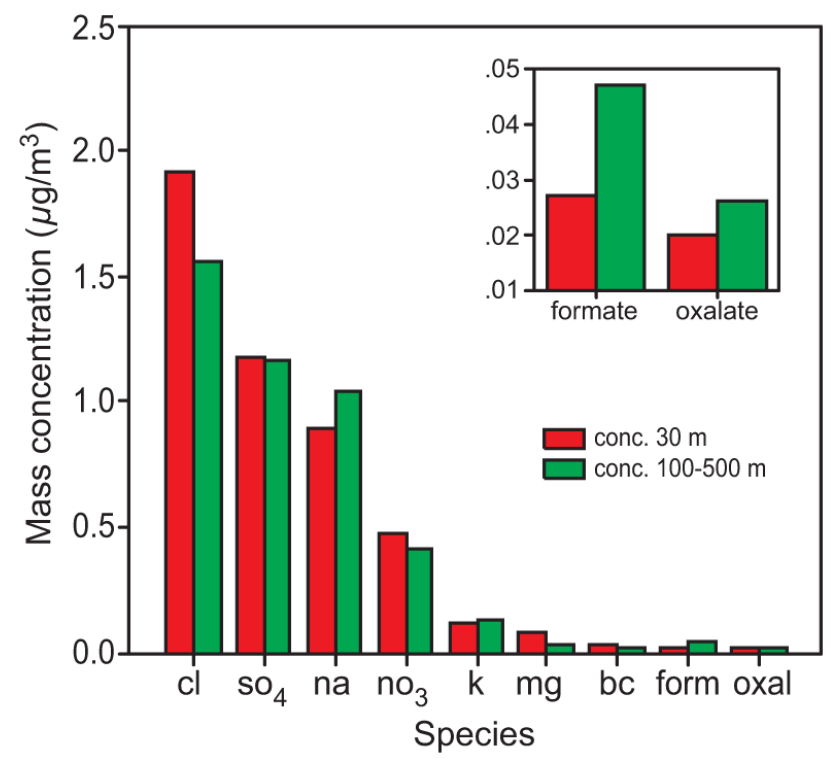

Fig. 2. Comparison of the mean chemical concentration of the dominant soluble chemical constituents of the aerosol at high $(>160 \mathrm{~m})$ and low altitude $(30 \mathrm{~m})$ during the study period. The associated DHGF spectra are shown in Fig. 1. The insert shows more clearly the changes in formate and oxalate. Total mass at low altitude $=10.2 \pm 1.5 \mu \mathrm{g} \mathrm{m}^{-3}$ and high altitude $=7.8 \pm 2.0 \mu \mathrm{g} \mathrm{m}^{-3}$.

two possible explanations for the increase in aerosol hygroscopicity with altitude, namely, oxidation of insoluble organics or secondary production of soluble inorganics. In the current data set, we have, in addition to the DHGF spectra themselves, some concurrent chemical composition data to allow us to make at least a preliminary evaluation of these two possibilities. However, prior to this assessment, it is worthwhile to eliminate another quite simple explanation: differential advection due to large-scale vertical shear. We feel this is very unlikely, not only because no such shear was observed but also simply because our observations were typically on the order of $20 \mathrm{~h}$ downwind from shore, and thus significant sources. Over such a time scale, vertical mixing would wipe out any vertical gradients. Only in situ chemical processes, whose time scale is much shorter than vertical mixing times, are feasible explanations for the observed differences with altitude. For the high and low altitude mean DHGF spectra shown in Fig. 1, concurrently sampled chemical composition data for soluble inorganics, formate and oxalate (black carbon is also shown because of its optical significance) are shown in Fig. 2. The species shown are those with the highest measured concentrations, the residual species being unlikely to influence the hygroscopicity significantly due to their relatively low concentration. While there are in fact some significant differences between the concentrations of the various species at the two altitudes, they are neither large nor systematic across species. Certainly the concentrations do not systematically increase with altitude (nor does the gravimetric 


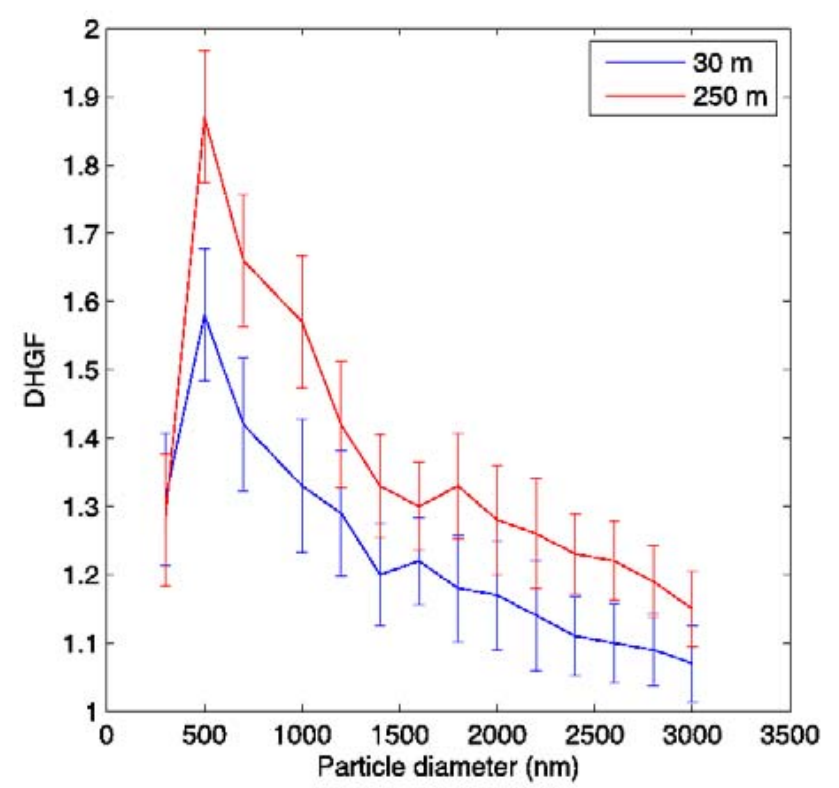

Fig. 3. Change in DHGF spectrum with altitude, Flight 817.

total mass significantly change). In accord with this, the mean soluble fraction of the aerosol, defined as the sum of all measured soluble species divided by the gravimetric mass, actually undergoes a slight (and insignificant) decrease with altitude (i.e. $0.40 \pm 0.06$ at the higher altitudes and $0.44 \pm 0.05$ at the lower). Hence, the hypothesis that the increase in hygroscopicity is associated with an increase in soluble inorganic salts such as sulfates receives little support here.

The alternative hypothesis, that of an oxidation of insoluble organics, perhaps including surface films, has no unequivocal supporting data either but there are some suggestive elements in the available data. As can be seen in the insert in Fig. 2, the formate and oxalate concentrations at the higher altitudes are 75 and $20 \%$ higher than at $30 \mathrm{~m} \mathrm{MSL}$, respectively. Both species are breakdown products of the oxidation of organics and oxalate, in particular, has been attributed to the breakdown of fatty acids in marine aerosol (e.g. Kawamura and Sakaguichi, 1999; Eliason et al., 2003; Turekian et al., 2003). Such fatty acids are known constituents of marine aerosols, are widely thought to coat them (cf. Cini and Loglio, 1997; Mochida et al., 2002; Tervahattu et al., 2002), and have long been considered likely candidates to inhibit hygroscopic growth by acting as a barrier to the interphase transport of water (cf. Gill et al., 1983; Ellison et al., 1999). They need be present only at quite low concentrations (see below) to form such a surface layer barrier. Further support for this possible scenario is provided by the few instances in which conditions were favorable for sampling by MOI's to acquire sized resolved chemical data congruent with the variation of DHGF's with altitude in homogeneous marine boundary layer air. Three such cases are available, all with winds uniformly from the Northwest with surface winds from $6-12 \mathrm{~m} \mathrm{~s}^{-1}$.

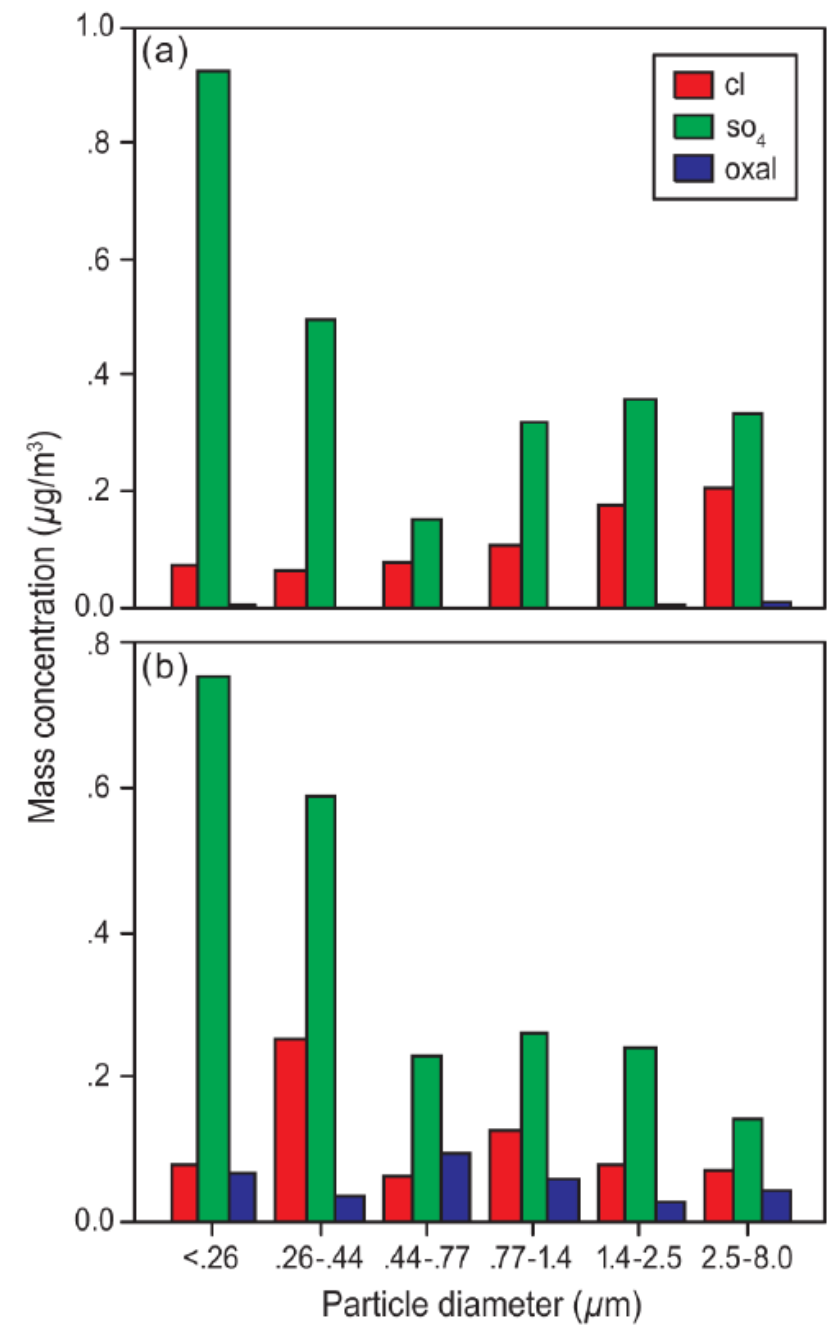

Fig. 4. (a) The chemical size distribution for $30 \mathrm{~m}$ altitude on Flt 817: total mass $=8.8 \pm 1.7 \mu \mathrm{g} \mathrm{m}^{-3}$ (b) The chemical size distribution for an altitude of $250 \mathrm{~m}$ on Flight 817 : total mass $=7.3 \pm 1.4 \mu \mathrm{g} \mathrm{m}^{-3}$.

The first such case, flight 811 (flight numbers consist of the month and day of month, e.g. 811 would the flight on $11 \mathrm{Au}-$ gust), shows a modest, relatively uniform increase in hygroscopicity over the entire size range at higher altitude but the accompanying chemical change is dominated by the diminution of the super-micron salt mass with altitude accompanied by a relative increase in sub-micron sulfate (not shown). Flight 817 shows a more substantial increase in hygroscopicity, again uniform over most of the size range (DHGF spectra shown in Fig. 3) but now accompanied by a more interesting chemical change. The MOI-derived chemical size distributions for the two sample altitudes of the DHGF spectra are shown in Fig. 4. The most striking feature of the chemical change with altitude is the presence of substantial oxalate (ca. $25 \%$ of total soluble mass) at the higher altitude, with the broad maximum in the distribution occurring in the same 


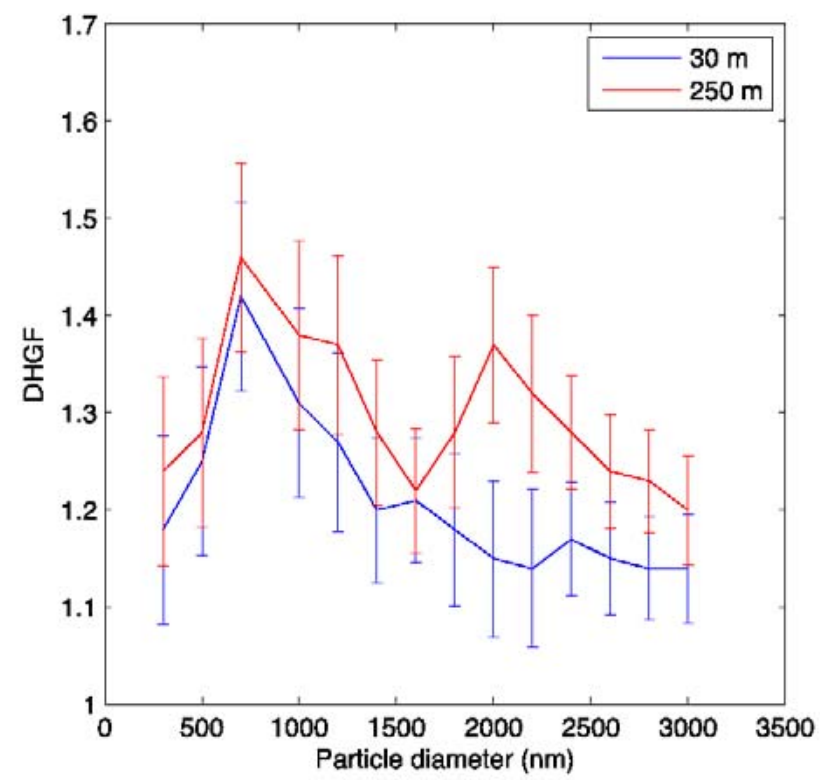

Fig. 5. Change in DHGF spectrum with altitude for Flight 815.

size range as the greatest change in hygroscopicity $(\sim 0.4-$ $1.4 \mu \mathrm{m}$ ), indeed, in the only portion of the size range for which the hygroscopicity change exceeds the measurement uncertainty. The last case, flight 815 , displays a somewhat more complex phenomenology. The DHGF spectra for this case are shown in Fig. 5. The hygroscopicity change is no longer uniform but shows a maximum peak in hygroscopicity gain at $2 \mu \mathrm{m}$. Overall, the change in hygroscopicity is most marked for the super-micron particles. Turning to the chemistry associated with these DHGF's (shown in Fig. 6), there is again an increase in oxalate with altitude and again it is maximized in the size range where the hygroscopicity gain is the greatest (and once again where it is clearly significant), now the super-micron size range. It is important to note, when considering this hypothesis, that very little oxalate, in an absolute sense, must be present for it to be viable. Thin organic films require very little actual mass to coat the marine size distribution, less than $1 \%$ being typically necessary to achieve a significant impact (cf. Mochida et al., 2002) and the products of thin film oxidation need therefore only be present in similar abundances. For example, for our size distributions, $\sim 5 \times 10^{-16}$ moles $\mathrm{cm}^{-3}$ would be required to coat the entire particle surface area. This translates into $\sim 0.02 \mu \mathrm{g} \mathrm{m}^{-3}$ of oxalate production even if the entire coating were oxidized - roughly what we observe.

While certainly not the only process occurring, these results do support the hypothesis that a significant portion of the increase in hygroscopicity with altitude is associated with the oxidation of organic surface films on the marine aerosol. However, an important aspect of this hygroscopicity reduction is not entirely clear, namely, is the effect kinetic, i.e. a reduction in the rate of aerosol growth, or an actual per-

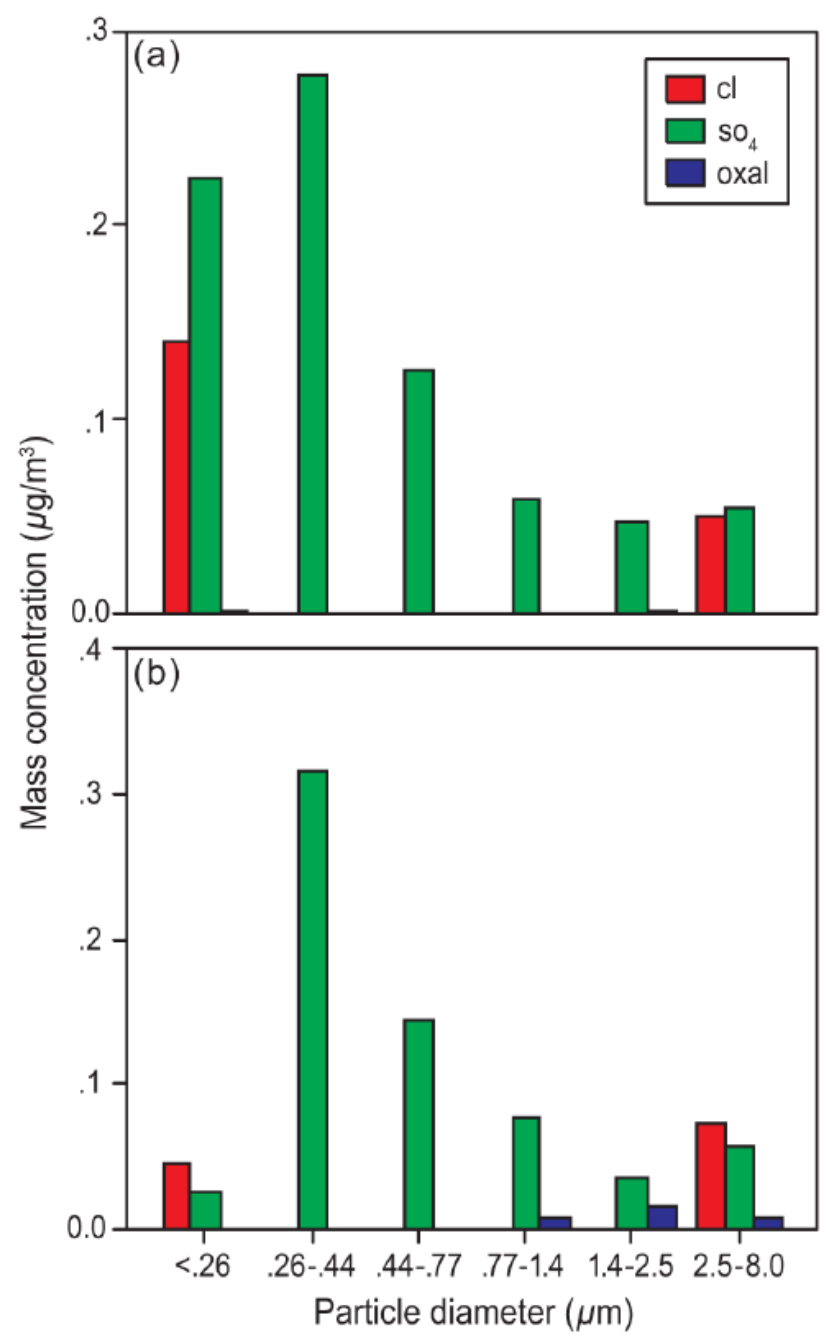

Fig. 6. (a) The chemical size distribution for an altitude of $30 \mathrm{~m}$ on Flight 815 . Total mass $=0.98 \pm 0.20 \mu \mathrm{g} \mathrm{m}^{-3}$ (b) The chemical size distribution for an altitude of $250 \mathrm{~m}$ on Flight 815 . total mass $=0.80 \pm 0.16 \mu \mathrm{g} \mathrm{m}^{-3}$.

manent - or at least long time scale - reduction in the water uptake below the equilibrium value for the uncoated solution haze particles? From previous measurements in which the AHS was used with an extended time period for condensational growth, and in which no kinetic effect was observed except in the case of biomass burning particles (Hegg et al., 2006, 2007), we tentatively conclude that our observations here reflect at least a long time scale (i.e. longer than vertical mixing times) reduced hygroscopicity. 


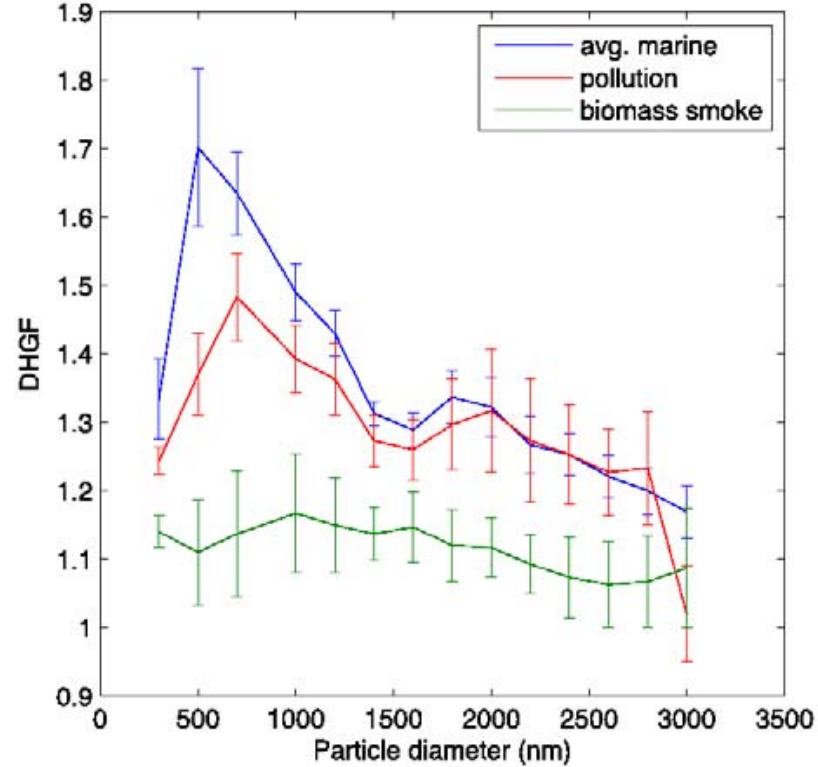

Fig. 7. Comparison of DHGF spectra for the three aerosol types in the study area.

\subsection{Observed pollution and biomass fire DHGF spectra}

While low levels of pollution are commonplace in the study area, on several occasions more substantial pollution was observed, mostly associated with "Southern Surges", i.e. inshore southerly flow extending up the California coast and advecting pollution from the urbanized Los Angeles basin. Furthermore, a very large and long-lived forest fire (the second largest in California history) took place during the study period and on a number of occasions the fire smoke haze was advected into our operational area. Mean DHGF spectra for clearly pollution and clearly biomass fire smoke cases (based on source attribution analysis to be discussed below) are shown in Fig. 7. Also shown, as a reference, is the mean marine spectrum for the higher altitudes $(\sim 250 \mathrm{~m} \mathrm{MSL}$, the closest in altitude to the mean pollution and smoke cases). Overall, the relationship between the different aerosol types is similar to that reported in Hegg et al. (2006) for CARMAIII but based on single examples. The pollution aerosol is somewhat less hygroscopic than the marine aerosol though now not significantly so above $\sim 1 \mu \mathrm{m}$. The fire smoke is significantly lower in hygroscopicity than either polluted or marine aerosol over virtually all sizes but with notably less size dependence in the DHGF's than the example in Hegg et al. (2006) suggested.

Chemically, as expected, the biomass samples contained far more carbon than did either of the other categories. They also contained much more nitrate. The pollution samples, on the other hand, were distinguished by relatively high soluble lead levels. However, more detailed discussion of differing chemistries is addressed below within the context of a broader issue: given that differing aerosol types are present, is it possible to predict how the hygroscopicities of these aerosol types would combine to produce an overall hygroscopicity of the aerosol at any particular locale? To address this issue, we first need a more quantitative assessment of aerosol sources.

\subsection{Aerosol sources from receptor modeling}

By far the longest established and most used technique for source attribution of atmospheric constituents is the chemical mass balance model (e.g. Friedlander, 1973; Cheng and Hopke, 1989; Fujita et al., 1994; Hidy and Venkataraman, 1996). So long as one has good source profiles (i.e. the chemical composition of all possible sources is well known), this technique is indeed preferred to most others since it is a well-posed mathematical problem with deterministic solution. However, quite commonly detailed source information is not available and one must then rely on various ANOVA techniques which utilize the internal variance of chemical compositions within a sample set to extract statistical source profiles which can then be used for source attribution. Perhaps the oldest such technique is factor analysis, generally with Principal Component Extraction, commonly referred to as PCA. More recent and powerful variations on this technique are Positive Matrix Factorization (PMF), developed by Paatero and his colleagues (cf. Paatero and Tapper, 1994) which puts various constraints on the matrix inversion to yield more physically plausible solutions, and the UNMIX model of Henry and his colleagues (cf. Henry, 2005), which uses geometric-based tools to detect "edges" or sources in the multi-dimensional spatial distribution of species. For the data presented here, there are no true source profiles available and we therefore turn to the factorization methodologies just discussed. These approaches are sometimes referred to as receptor modeling. Specifically, we use the operational EPA receptor models PMF 1.1 and UNMIX 2.3 to determine the source profiles and source contributions to each aerosol sample. Because the UNMIX model is better at objectively assessing the number of sources truly present, we rely on it most heavily.

The available data set consists of the concentrations of 18 chemical species analyzed in each of 24 filter samples measured concurrently with a DHGF spectrum and a measure of the impact of RH on aerosol light scattering (the Kasten "gamma" parameter; cf. Gasso et al., 2000). From these, several derivative variables such as non sea salt (NSS) sulfate and potassium, and water of hydration were calculated. In the last instance, the water of hydration was calculable in a straightforward way from the AHS data but for the humdigraph, a more complex procedure needed to be followed. First the scattering ratio was converted to a diameter ratio as per Gasso et al. (2000). The additional water mass at the higher RH was then calculated in a straightforward manner under the assumption of volume additivity as 
Table 1. The variables used in the receptor modeling analysis.

\begin{tabular}{|c|c|c|c|c|}
\hline variable & maximum & mean & minimim & se of mean \\
\hline $\mathrm{Cl}$ & 4.93 & 1.28 & 0 & 0.30 \\
\hline $\mathrm{NO}_{3}$ & 2.97 & 0.56 & 0.17 & 0.12 \\
\hline $\mathrm{SO}_{4}$ & 2.69 & 1.25 & 0.37 & 0.13 \\
\hline Oxalate & 0.92 & 0.09 & 0 & 0.04 \\
\hline $\mathrm{Mg}$ & 0.21 & 0.04 & 0 & 0.015 \\
\hline $\mathrm{Na}$ & 2.64 & 0.81 & 0 & 0.17 \\
\hline $\mathrm{Pb}$ & 3.58 & 0.47 & 0 & 0.16 \\
\hline Total Dry Mass & 73.77 & 16.32 & 4.27 & 3.47 \\
\hline NSS_K & 0.46 & 0.11 & 0 & 0.02 \\
\hline $\mathrm{NSS} \_\mathrm{SO}_{4}$ & 2.61 & 1.04 & 0.29 & 0.121 \\
\hline Soluble Mass & 13.6 & 5.29 & 1.53 & 0.70 \\
\hline Black Carbon & 3.88 & 0.26 & 0.002 & 0.17 \\
\hline $\mathrm{H}_{2} \mathrm{O}_{-}$submicron ${ }^{1}$ & 75.7 & 22.3 & 0.71 & 4.43 \\
\hline $\mathrm{H}_{2} \mathrm{O}$ _supermicron ${ }^{1}$ & 20.35 & 7.13 & 0.93 & 1.26 \\
\hline $\mathrm{H}_{2} \mathrm{O}_{-}$scattering ${ }^{1}$ & 15.65 & 6.51 & 1.33 & 0.87 \\
\hline
\end{tabular}

${ }^{1}$ The water of hydration associated with the sub- and super-micron portions of the size distribution, as measured by the AHS, or indicated by the humidigraph for the change in the light-scattering with $\mathrm{RH}$ going from $\sim 45-85 \%$. The units are in $\mu \mathrm{g} \mathrm{m}^{-3}$.

per Hanel (1976). On the other hand, several species were eliminated from use a priori due to a low incidence of above detection limit concentrations - which led to a poor signalto-noise ratio. Unfortunately, one such set of species was the carbohydrates, including levoglucosan. This species has been widely used as an excellent biomass burning tracer (cf. Simoneit et al., 1999; Gao et al., 2003a) but was only present in seven of the samples in the data set. However, a correlation analysis between this species and several other plausible biomass burning tracers revealed excellent correlations $\left(R^{2}\right.$ for NSS_K $=0.97$, for oxalate $=0.96$, black carbon $=0.98$ ) that we utilize in interpreting the source profiles. The set of variables actually used in the variance analysis, together with descriptive statistics, is shown in Table 1. While both the PMF and UNMIX models were used on the data set, they gave essentially the same results and, in the interest of brevity, we will deal solely with the UNMIX results from this point on.

Exercised on the data summarized in Table 1, the model found feasible solutions to the matrix inversion only for three factors or sources. Total mass was used for both the normalization variable and to constrain the sum of loadings ("Total" variable in UNMIX). The source profiles derived by the model are shown in Table 2. We first note that the small negative loadings - which are of course not realistic - are well within the uncertainties in the loading variables (based on bootstrapping, Efron and Tibshirani, 1996). Interpretation of the source profiles, i.e. source identification, can be problematic at times but in this instance is fairly straightforward. Source three is perhaps the easiest to identify. It contains the highest loadings by far of both $\mathrm{Cl}$ and $\mathrm{Na}$. These species are present, furthermore, in almost exactly the mass ratio found
Table 2. The source profiles (component loadings) derived from the UNMIX model. With the exception of the mass normalization and hydration variable $(s)$, the units are the mass fractions. The waters of hydration are water to dry mass ratios and the total mass is in mass per unit volume of air.

\begin{tabular}{|c|c|c|c|}
\hline Species & source_1 & source $\_2$ & source_3 \\
\hline CL & 0.0526 & 0.0233 & 0.1907 \\
\hline $\mathrm{NO}_{3}$ & 0.0248 & 0.0465 & 0.0351 \\
\hline $\mathrm{SO}_{4}$ & 0.085 & 0.043 & 0.1073 \\
\hline OXALATE & 0.0036 & 0.0136 & 0.0009 \\
\hline $\mathrm{Mg}$ & 0.0005 & 0.0016 & 0.0086 \\
\hline $\mathrm{Na}$ & 0.0295 & 0.0295 & 0.1081 \\
\hline $\mathrm{Pb}$ & 0.1558 & 0.0015 & 0.006 \\
\hline TOTAL DRY MASS & 3.077 & 5.6725 & 5.5555 \\
\hline NSS_K & 0.0054 & 0.0079 & 0.0085 \\
\hline $\mathrm{NSS}_{-} \mathrm{SO}_{4}$ & 0.0777 & 0.0355 & 0.0801 \\
\hline SOLUBLE MASS & 0.3728 & 0.2508 & 0.4831 \\
\hline Black carbon & -0.004 & 0.0558 & -0.0026 \\
\hline $\mathrm{H}_{2} 0 \mathrm{SUBMICRON}^{1}$ & 1.0538 & 0.4373 & 2.8052 \\
\hline $\mathrm{H}_{2} 0$ SUPERMICRON $^{1}$ & 0.5951 & 0.1351 & 0.7942 \\
\hline $\mathrm{H}_{2} \mathrm{O}$ from humidigraph ${ }^{1}$ & 0.5354 & 0.119 & 0.69 \\
\hline
\end{tabular}

${ }^{1}$ The water of hydration associated with the sub- and super-micron portions of the size distribution, as measured by the AHS, or indicated by the humidigraph for the change in the light-scattering with RH going from $45-85 \%$.

in sea water $(\mathrm{Cl} / \mathrm{Na}=1.8)$. Hence, interpretation of the factor or source as sea-salt aerosol is reasonably firm. The second source has a slightly less secure but nevertheless very credible interpretation. The loadings of both oxalate and black carbon are, again, by far the highest in this source and, as discussed above, both are plausible biomass tracers. Surprisingly, the NSS_K is not decisively partitioned into this source, as would be expected. On the other hand, nitrate is preferentially loaded, which is consistent with a biomass burning source. The most uncertain source to interpret is source one. The only truly distinguishing characteristic of this source profile is the overwhelming loading of soluble $\mathrm{Pb}$. Since this is highly characteristic of pollution aerosol, we feel justified in identifying this source as anthropogenic pollution. This source inventory is entirely consistent with what was known a priori about the potential sources for this operational area, as discussed above.

Having a plausible source inventory in hand, the next step in the receptor modeling exercise is to quantify the contribution of each source to each of the 24 samples in the data base. This, of course, is done automatically by the UNMIX model and the model predicted source contributions are shown in Fig. 8. To facilitate later calculations, the contributions are shown as mass fractions of the total aerosol mass present. It can be seen that in about a third of the cases the aerosol is dominated by sea salt (i.e. $\sim 75 \%$ of the mass is 


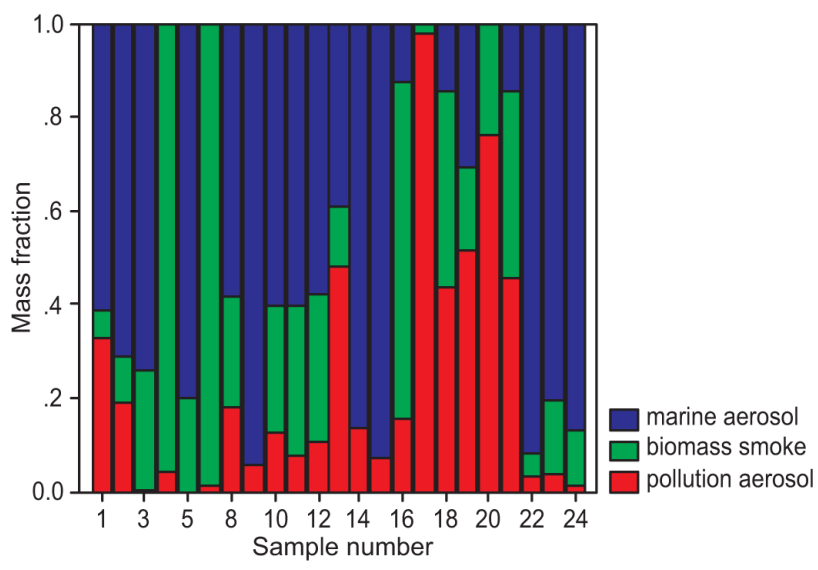

Fig. 8. Mass fractions of each of the three aerosol types in the study area for each of the aerosol samples analyzed.

associated with the sea salt source). The two cases shown for which biomass smoke dominated the aerosol are both associated with 4 day back trajectories (HYSPLIT-IV) that passed within a few $\mathrm{km}$ of the Santa Barbara fire discussed above. A third sample (case 16 corresponding to the flight on 24 August also had a pronounced biomass component and a back trajectory that closed to within $\sim 100 \mathrm{~km}$ of the fire column. Hence, the source attribution is broadly consistent with meteorological data for the fire source. Similarly, pollution aerosol was most evident for cases 17-21, corresponding to the samples taken offshore during 25 and 26 August, days during which southerly flow along the coast was present, advecting air from the polluted South Coast Air Basin.

\subsection{Hygroscopicity mixing rule}

Various approaches have been implemented to combine the contributions of different aerosol types into the overall aerosol hygroscopicity. For example, Gao et al. (2003b) used tracers for several types and estimates of the growth factors associated with each type based on a literature survey. The type growth factors were then combined as a weighted sum, the weighting being the tracer concentrations. A less ad hoc approach has been to use the well known Zdanovskii, Stokes and Robinson (ZSR) relationship, which essentially assumes that the water mass of hydration of a mixed aerosol particle is the linear sum of the water masses that would be associated with the masses of each chemical component of it, i.e. there are no interaction terms between different solutes that impact the water activity (cf. Stokes and Robinson, 1966). This can be shown to lead to the following mixing rule for aerosol hygroscopic growth factors:

$G F_{\text {tot }}=\left(\sum_{i}^{n} \varepsilon_{i} G F_{i}(\mathrm{RH})^{3}\right)^{\frac{1}{3}}$ where $\varepsilon_{i}$ is the volume fraction of the ith component of the aerosol and $G F_{i}$ is the hygroscopic growth factor for a given $\mathrm{RH}$ (or DHGF in our case) that would be associated with a particle composed of the ith species alone (cf. Chen et al., 1973; Gysel et al., 2004).

This approach has been used with some success to predict the hygroscopic growth of mixed particles based on the growth factors for pure chemical species derived from laboratory studies (e.g. Aklilu et al., 2006; Gysel et al., 2007). We employ this methodology here but now using DHGF's characteristic of the three aerosol types derived from our receptor model. To quantify these, we have averaged the measured values for cases that the receptor analysis itself has suggested were dominated by one of the aerosol types. Another simplification, to render comparison of predictions with measurements less unwieldy, has been to collapse the size dependent DHGF's into two values, one characteristic of the sub and one of the super-micron size range. For the sub-micron range, we have used the average of DHGF values from 0.3 to $0.7 \mu \mathrm{m}$ and for the super-micron range, DHGF's over the range 1.8 to $2.2 \mu \mathrm{m}$. We have, additionally, calculated a DHGF for particles in the effective light-scattering range based on the $\mathrm{RH}$ dependence of the aerosol light scattering as measured by the humidigraph. This DHGF, while certainly related to the sub-micron DHGF measured by the AHS, is not identical to it and will vary with changes in the aerosol size distribution in the submicron range as well as with the corresponding chemistry. For the aerosol size distributions measured during this study, which have a significant portion below the $0.3 \mu \mathrm{m}$ lower limit of the AHS, differences in the two DHGF's should be expected. Following the above procedure, we arrive at values for the submicron DHGF's of 1.13, 1.62 and 1.34 for biomass, marine and polluted aerosols, respectively. The corresponding scattering DHGF's are 1.11, 1.22 and 1.21. These values are consistent with previous measurements on similar aerosol types (e.g. Swietlicki et al., 2000; Rissler et al., 2004). For supermicron values, we estimate $1.11,1.25$ and 1.25 for biomass, marine and polluted aerosol types. There is little previous data with which to compare these values but the pollution value, at least, is consistent with the work of Hitzenberger et al. (1997).

Finally, the receptor modeling output for the contribution of the various sources to individual samples is in units of mass per unit volume of air. From this, mass fractions of the components were easily calculable (cf. Fig. 8). We have assumed that the density differences between the different aerosol types are relatively slight and that the mass fractions can be used as volume fractions in Eq. (1).

With these assumptions, prognostic values for super and sub-micron DHGF's, and for a "scattering" DHGF have been calculated and compared with the measurements. The regression analysis for the sub-micron range is shown in Fig. 9. The agreement, while not truly impressive, is quite reasonable, with an $R^{2}$ value of 0.64 , significant at $>99.9 \%$ level. 
Similarly, the predicted and measured "scattering" DHGF's have a reasonable $R^{2}$ value of 0.56 . These values are quite comparable to those found for the use of the ZSR mixing rule with laboratory derived values of growth factors for pure species (Aklilu et al., 2006; Gysel et al., 2007). On the other hand, the regression $R^{2}$ for the super-micron hygroscopicity is only 0.11 , suggesting no prognostic power for the ZSR mixing rule. A rationalization for this discrepancy is not difficult to find. The mass size distribution for the data set we have employed (based on the MOI samples collected), peaks in the 0.26 to $0.44 \mu \mathrm{m}$ size range. Since the filter data used for the chemical composition of course yield bulk composition, that data is most characteristic of this size range - the size range for the sub-micron DHGF's. The scattering by the particles will also be heavily influenced by particles in this size range, which falls in the effective Mie scattering range (cf. Yuen et al., 1994). On the other hand, the super-micron composition can, in general, be poorly represented by the bulk composition data and the source attribution for the bulk mass therefore not representative of that for the super-micron aerosol.

\section{Conclusions}

Measurements of the hygroscopic growth of ambient aerosols off the central California coast are broadly consistent with previous measurements in the same area, both with respect to the most common marine aerosol and to that of the other aerosol types that commonly are present here, pollution and biomass smoke. The measured DHGF spectra in a well-mixed, MBL consistently exhibited more hygroscopicity at higher altitudes. Concurrent measurements of the aerosol chemical composition suggest that this is unlikely to be due to secondary production of soluble inorganic mass (e.g. sulfate) but could plausibly be attributed to the oxidation of organic surface films as per the hypothesis of Ellison et al. (1999). A receptor modeling exercise was carried out in order to quantitatively assess the impact of different aerosol types/sources on the aerosol hygroscopicity in the study area. Both the EPA PMF 1.1 and UNMIX 2.3 models were utilized. The results indicated, as expected, that the composition of the aerosol was dominated by three aerosol types, marine, biomass smoke and pollution. Model predictions of the contribution of these sources to the mass of 24 aerosol samples were used together with the ZSR mixing rule to predict the overall hygroscopicity of the aerosols sampled. For the sub-micron and "scattering" hygroscopicity, considerable prognostic power was demonstrated but not for the super-micron hygroscopicity. This can be attributed to the bulk chemistry used in the analysis, which would not, in general, be representative of the larger particle composition. To address this flaw, size resolved chemical composition data would be necessary.

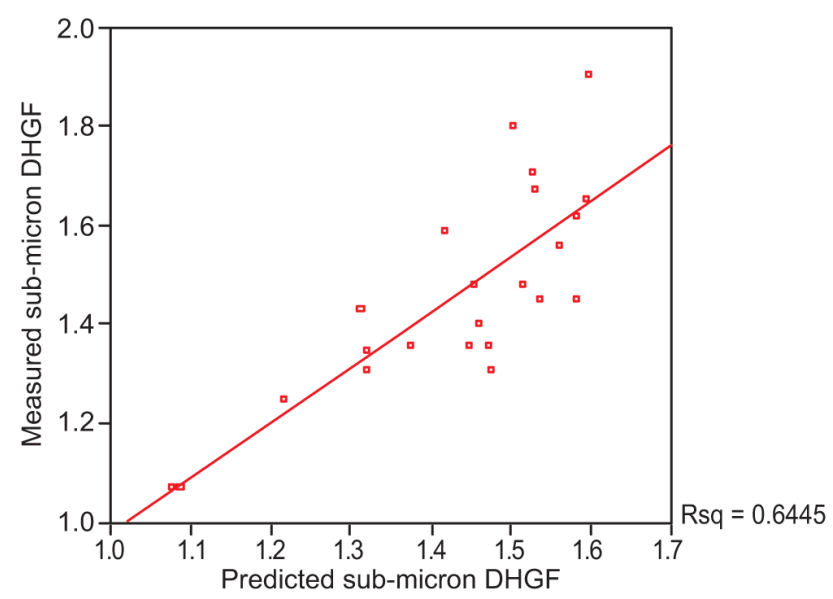

Fig. 9. Regression analysis of the predicted and measured submicron DHGF's during the study period.

Acknowledgements. This research was supported by ONR grant N00014-07-1-0277. The authors wish to thank Tim Larson for many valuable discussions. Back trajectories used in this study were calculated with HYSPLIT4 (HYbrid Single-Particle Lagrangian Integrated Trajectory) Model, 1997. Web address: http://www.arl.noaa.gov/ready/hysplit4.html, NOAA Air Resources Laboratory, Silver Spring, MD. We wish to thank three anonymous reviewers for useful comments.

Edited by: G. Roberts

\section{References}

Andreae, M. O.: Aerosols before pollution, Science, 315, 50-51, 2007.

Aklilu, Y., Mozurkewich, M., Prenni, A. J., Kreidenweis, S. M., Alfarra, M. R., Allan, J. D., Anlauf, K., Brook, J., Leaitch, W. R., Sharma, S., Boudries, H., and Worsnop, D. R.: Hygroscopicity of particles at two rural, urban influenced sites during Pacific 2001: comparison with estimates of water uptake from particle composition, Atmos. Environ., 40, 2650-2661, 2006.

Bond, T. C. and Bergstrom, R. W.: Light absorption by carbonaceous particles: an investigative review, Aerosol Sc. Technol., 40, 1-41, 2006.

Charlson, R. J., Schwartz, S. E., Hales, J. M., Cess, R. D., Coakley Jr., J. A., Hansen, J. E., and Hoffmann, D. J. : Climate Forcing by Anthropogenic Aerosols, Science, 255, 423-430, 1992.

Chen, H., Sangster, J., Teng, T. T., and Lenzi, F.: General method of predicting water activity of ternary aqueous-solutions from binary data, Can. J. Chem. Eng., 51, 234-241, 1973.

Cheng, M. D. and Hopke, P. K.: Identification of markers for chemical mass balance receptor model, Atmos. Environ., 23, 13731384, 1989.

Cini, R. and Loglio, G.: Adsorption and pollutant transport by marine aerosol, Mar. Pollut. Bull., 34, 501-504, 1997.

Durkee, P. A., Noone, K. J., Ferek, R. J., Johnson, D. W., Taylor, J. P., Garrett, T. J., Hobbs, P. V., Hudson, J. G., Bretherton, C. S., Innis, G., Frick, G. M., Hoppel, W. A., O’Dowd, C. D., 
Russell, L. M., Gasparovic, R., Nielsen, K. E., Tessmer, S. A., Ostrom, E., Osborne, S. R., Flagan, R. C., Seinfeld, J. H., and Rand, H.: The Impact of Ship-Produced Aerosols on the Microstructure and Albedo of Warm Marine Stratocumulus Clouds, A Test of the MAST Hypothesis Li and Lii, J. Atmos. Sci., 57, 2554-2569, 2000.

Eliason, T. L., Gilman, J. B., and Vaida, V.: Oxidation of organic films relevant to atmospheric aerosols, Atmos. Environ., 38, 1367-1378, 2003.

Efron, B. and Tibshirani, R. J.: An Introduction to the Bootstrap, Chapman and Hill, New York, 1996.

Ellison, G. B., Tuck, A. F., and Vaida, V.: Atmospheric processing of organic aerosols, J. Geophys. Res., 104, 11 633-11 641, 1999.

Friedlander, S. K.: Chemical mass balances and identification of air pollution sources, Environ. Sci. Technol., 7, 235-240, 1973.

Fujita, E. M., Watson, J. C., Chow, J. C., and Lu, Z.: Validation of the chemical mass balance receptor model applied to hydrocarbon source apportionment in the Southern California Air Quality Study, Environ. Sci. Technol., 28, 1633-1649, 1994.

Gao, S., Hegg, D. A., Covert, D. S., and Jonsson, H.: Aerosol chemistry, and light-scattering and hygroscopicity budgets during ACE-Asia, J. Geophys. Res., 46, 55-88, 2003 a.

Gao, S., Hegg, D., Covert, D., Jonsson, H.: Aerosol chemistry, and light-scattering and hygroscopicity budgets during outflow from East Asia, J. Atmos. Chem., 46, 55-88, 2003b.

Gasparini, R., Collins, D. R., Andrews, E., Sheridan, P. J., Ogren, J. A., and Hudson, J. G.: Coupling aerosol size distributions and size-resolved hygroscopicity to predict humidity-dependent optical properties and cloud condensation nuclei spectra, J. Geophys. Res., 111, D05S13, doi:10.1029/2005JD006092, 2006.

Gasso, S., Hegg, D. A., Covert, D. S., Collins, D., Noone, K. J., Ostrom, E., Schmid, B., Russell, P. B., Livingston, J. M., Durkee, P. A., and Jonsson, H.: Influence of humidity on the aerosol scattering coefficient and its effect on the upwelling radiance during ACE-2, Tellus, 52B, 546-567, 2000.

Gill, P. S., Graedel, T. E., and Weschler, C. J: Organic Films on Atmospheric Aerosol-Particles, Fog Droplets, Cloud Droplets, Raindrops, and Snowflakes, Rev. Geophys., 21, 903-920, 1983.

Gysel, M., Crosier, J., Topping, D. O., Whitehead, J. D., Bower, K. N., Cubison, M. J., Williams, P. I., Flynn, M. J., McFiggans, G. B., and Coe, H.: Closure study between chemical composition and hygroscopic growth of aerosol particles during TORCH2, Atmos. Chem. Phys., 7, 6131-6144, 2007, http://www.atmos-chem-phys.net/7/6131/2007/.

Hanel, G.: The properties of atmospheric aerosol particles as functions of the relative humidity at thermodynamic equilibrium with the surrounding moist air, Adv. Geophys., 19, 73-188, 1976.

Gysel, M., Weingartner, E., Nyeki, S., Paulsen, D., Baltensperger, U., Galambos, I., and Kiss, G.: Hygroscopic properties of water-soluble matter and humic-like organics in atmospheric fine aerosol, Atmos. Chem. Phys., 4, 35-50, 2004,

http://www.atmos-chem-phys.net/4/35/2004/.

Hegg, D. A., Covert, D. S., and Crahan, K.: The dependence of aerosol light-scattering on RH over the Pacific Ocean, Geophys. Res. Lett., 29, 1219, doi:10.1029/2001GL014495, 2002.

Hegg, D. A., Covert, D. S., Crahan, K. K., Jonsson, H. H., and Liu, Y.: Measurements of the Aerosol Size-Resolved Hygroscopicity at Sub and Supermicron Sizes, Geophys. Res. Lett., 33, L21808, doi:10.1029/2006GL026747, 2006.
Hegg, D. A., Covert, D. S., Jonsson, H., and Covert, P. A.: Determination of the transmission efficiency of an aircraft aerosol inlet, Aerosol Sci. Technol., 39, 966-971, 2005.

Hegg, D. A., Covert, D. S., Jonsson, H., and Covert, P. A.: An instrument for measuring size-resolved hygroscopicity at both sub- and super-micron sizes, Aerosol Sci. Technol., 41, 873-883, 2007.

Hegg, D. A., Livingston, J. ., Hobbs, P., Novakov, T., and Russell, P.: Chemical apportionment of aerosol column optical depth off the mid-Atlantic coast of the United States, J. Geophys. Res., 102, 25 293-25 303, 1997.

Henry, R. C.: Duality in multivariate receptor models, Chemom. Intell. Lab. Syst., 77, 59-63, 2005.

Hidy, G. M. and Venkataraman, C.: The chemical mass balance method for estimating atmospheric particle sources in Southern California, Chem. Eng. Comm., 151, 187-209, 1996.

Hitzenberger, R., Berner, A., Dusek, U., and Alabashi, R.: Humidity-dependent growth of size-segregated aerosol samples, Aerosol Sci. Technol., 27, 116-130, 1997.

Kawamura, K. and Sakaguchi, F.: Molecular distribution of water soluble dicarboxylic acids in marine aerosols over the Pacific Ocean including the tropics, J. Geophys. Res., 104, 3501-3509, 1999.

Kim, E., Hopke, P. K., Larson, T. V., and Covert, D. S.: Analysis of ambient particle size distributions using unmix and positive matrix factorization, Environ. Sci. Technol., 38, 202-209, 2004.

Kreisberg, N. M., Stolzenberg, M. R., Hering, S. V., Dick,W. D., and McMurry, P. H.: A New Method for Measuring the Dependence of Particle Size Distributions on Relative Humidity, with Application to Southeastern Aerosol and Visibility Study, J. Geophys. Res., 106(D14), 14 935-14 949, 2001.

Mochida, M., Kitamori, Y., and Kawamura, K.: Fatty acids in the marine atmosphere: factors governing their concentrations and evaluation of organic films on sea-salt particles, J. Geophys. Res., 107, 4325, doi:10.1029/2001JD001278, 2002.

Nowak, A.: Das Feuchte Partikelgroessenspktrometer: Eine Neue Messmethode Zur Bestimmung Von Partikelgroessenverteilung $(<1 \mu \mathrm{m})$ und Groessenaufgeloesten Hygroskopischen Wachsumsfaktoren Bei Definierten Luftfeuchten, Doctoral Thesis, Leibnitz Institute for Tropospheric Research, Permoserstr. 15, 04303 Leipzig, Germany, 2005.

Paatero, P. and Tapper, U.: Positive matrix factorization: a nonnegative factor model with optimal utilization of error estimates of data values, Environmetrics, 5, 111-126, 1994.

Platnick, S. and Twomey, S.: Determining the Susceptibility of Cloud Albedo to Changes in Droplet Concentration with the Advanced very High-Resolution Radiometer, J. Appl. Meteor., 33, 334-347, 1994.

Pöschl, U., Rudich, Y., and Ammann, M.: Kinetic model framework for aerosol and cloud surface chemistry and gas-particle interactions Part 1: General equations, parameters, and terminology, Atmos. Chem. Phys., 7, 5989-6023, 2007, http://www.atmos-chem-phys.net/7/5989/2007/.

Rossi, M. J.: Heterogeneous Reactions on Salts, Chem. Rev., 103, 4823-4882, 2003.

Rissler, J., Swietlicki, E., Zhou, J., Roberts, G., Andreae, M. O., Gatti, L. V., and Artaxo, P.: Physical properties of the submicrometer aerosol over the Amazon rain forest during the wetto-dry season transition - comparison of modeled and measured 
CCN concentrations, Atmos. Chem. Phys., 4, 2119-2143, 2004, http://www.atmos-chem-phys.net/4/2119/2004/.

Rudich, Y.: Laboratory Perspectives on the Chemical Transformations of Organic Matter in Atmospheric Particles, Chem. Rev., 103, 5097-5124, 2003.

Santarpia, J. L., Runjun, L., and Collins, D. R.: Direct Measurement of the Hydration State of Ambient Aerosol Populations (2004), J. Geophys. Res., 109, D18209, doi:10.1029/2004JD004653, 2004.

Schmid, B., Hegg, D. A., Wang, J., Bates, D., Redemann, J., Russell, P. B., Livingston, J. M., Jonsson, H. H., Welton, E. J., Seinfeld, J. H., Flagan, R. C., Covert, D. S., Dubovik, O., and Jefferson, A.: Column Closure Studies of the Lower Tropospheric Aerosol and Water Vapor during ACEAsia Using Airborne Sunphotometer, Airborne In-Situ and Ship-Based Lidar Measurements, J. Geophys. Res., 108, 8656, doi:10.1029/2002JD003361, 2003.

Simoneit, B. R. T., Schaur, J. J., Nolte, C. G., Oros, D. R., Elias, V. O., Naser, M. P., Rogge, W. J., and Cass, G. R.: Levoglucsan: a tracer for cellulose in biomass burning and atmospheric particles, Atmos. Environ., 33, 173-182, 1999.

Stokes, R. H. and Robinson, R. A.: Interactions in aqueous nonelectrolyte solutions, I. Solute-solvent equilibria, J. Phys. Chem., 70, 2126-2131, 1966.

Swietlicki, E., Zhou, J., Covert, D. S., Hameri, K., Busch, B., Vakeva, M., Dusek, U., Berg, O. H., Widensohler, A., Aalto, P., Makela, J., Martinsson, B. G., Papaspiropoulos, G., Mentes, B., Frank, G., and Stratmann, F.: Hygroscopic Properties of Aerosol Particles in the Northeastern Atlantic during ACE-2, Tellus, 52B, 201-227, 2000.

Tervahattu, H., Juhanoja, J., and Kupianinen, K.: Identification of an organic coating on marine aerosol particles byTOF-SIMS, J. Geophys. Res.-Atmos., 107, 4319, doi:10.1029/2001JD001403, 2002.
Turekian, V. C., Macko, S. A., and Keene, W. C.: Concnetrations, isotopic compositions, and sources of size-resolved, particulate organic carbon and oxalate in near-surface marine air at Bermuda during spring, J. Geophys. Res., 108, 4157 doi:10.1029/2002JD002053, 2003.

Virkkula, A., Ahlquist, N. N., Covert, D. S., Arnott, W. P., Sheridan, P. J., Quinn, P. K., and Coffman, D. J.: Modification, calibration and a field test of an instrument for measuring light absorption by particles, Aerosol Sci. Technol., 39, 68-83, 2005.

Wang, J., Flagan, R. C., Seinfeld, J. H., Jonsson, H. H., Collins, D. R., Russell, P. B., Schmid, B., Redemeann, J., Livingston, J. M., Gao, S., Hegg, D. A., Welton, E. J., and Bates, D.: Clear-Column Radiative Closure during ACE-Asia: Comparison of Multiwavelength Extinction Derived from Particle size and Composition with Results from Sunphotometry, J. Geophys. Res., 107(D23), 4688, doi:10.1029/2002JD002465, 2002.

Warren, S. G., Hahn, C. J., London, J., Chervin, R. M., and Jenne, R. L.: Global Distribution of Total Cloud Cover and Cloud type Amounts Over the Ocean, NCAR Technical Note NCAR/TN317+STR, 1988.

Willis, R. D., Ellenson, W. D., and Conner, T. L.: Monitoring and source apportionment of particulate matter near a large phosphorous production facility, J. Air and Waste Manage. Assoc., 51, 1142-1166, 2001.

Yuen, P.-F., Hegg, D. A., and Larson, T. V.: The effects of in-cloud sulfate production on light-scattering properties of continental aerosol, J. Appl. Meteorol., 33, 848-854, 1994. 